УдК $\quad 355.11(=162.3)^{\prime \prime 1914 / 1918 ” ~}$

Прегледни рад

Примљен: 16.12. 2016.

Прихваћен:16. 1. 2017.

\author{
Ladislav HLADKÝ \\ Institute of History, \\ Academy of Sciences of the Czech Republic, Brno \\ hladky@brno.avcr.cz
}

\title{
Czech Soldiers during the Great War (1914-1918)*
}

\begin{abstract}
The goal of this article is to objectively assess the conduct of Czech soldiers during the First World War. In the past, this issue was, for various ideological reasons, greatly oversimplified. German national propaganda portrayed Czech soldiers fighting in the uniforms of the Austro-Hungarian Army in the period 1914-1918 as a very unreliable element, owing to their Slavic sentiments. However, after 1918 the Czechoslovak Republic also adopted a very critical position toward these soldiers, as the main credit for the founding of the independent state was ascribed to the so-called legionnaires, i.e. to the soldiers who fought on the side of the Allied states. In this article the author reflects upon the Czech historiographic production on the First World War at the turn of the $20^{\text {th }}$ and $21^{\text {st }}$ centuries and attempts to present a balanced (non-national) perspective on the subject.

Key words: First World War, Austria-Hungary, Czech soldiers, Eastern (Russian) front, Southwest (Italian) front, Czechoslovak legionnaires, Czechoslovakia
\end{abstract}

The naissance of the independent Czechoslovak Republic in 1918, which arose as a consequence of the dissolution of Austria-Hun-

* This article originated under the auspices of a grant supported by the Grant Agency of the Czech Republic: P410/12/1136, T. G. Masaryk a Slované. 
gary at the end of the First World War, as the culmination of a long-term liberation struggle of the Czech and Slovak nations against several centuries-long domination of the Austrian Habsburgs. ${ }^{1}$ In the interwar period the main credit for the founding of the Republic was attributed to anti-Austrian foreign emigrants led by Tomáš Garrigue Masaryk as well as to the Czechoslovak soldiers who volunteered abroad, the so-called legionnaires. These units were established during the war in Russia (approximately 60 thousand Czechoslovak legionnaires), in France (10 thousand), and in Italy (20 thousand), and they fought against Germany and Austria-Hungary on behalf of the Allied states. ${ }^{2}$ After the war, these men were celebrated as having unambiguously been the principal heroes in the Czechoslovak Republic and it is even possible to state that a certain cult of the legionnaires was cultivated in the Czech milieu in the interwar period. After 1918, in order to also preserve their important positions in the society after the war, the legionnaires began to associate through an organization named the Czechoslovak Association of Legionaries. They occupied the most important positions in the Czechoslovak Army and police, and many of them also became involved in in the highest echelons of politics, e.g. General Silvestr Bláha, who in 1928-1938 held the position of the Head of Presidential Military Bureau of T. G. Masaryk and E. Beneš, or General Jan Syrový, who in the interwar period twice held the position of Minister of Defense and at the end of 1938 (during so-called Munich Crisis) even became Czechoslovak Prime Minister.

On the other side of the front, tens of thousands Czech soldiers had laid down their lives in the First World War for the Austrian Emperor and their homeland of that time - the Habsburg Empire. The total number of Czech soldiers who fell during the First World War in the uniforms of the Austro-Hungarian Army is still not known, but it is estimated at around 130-150 thousand (not counting hundreds of thousands of veterans who were injured or became permanent invalids). ${ }^{3}$ This is

1 Ivan Šedivý, Češi, české země a Velká válka 1914-1918, (Praha: Nakladatelství Lidové noviny, 2001); Robert Kvaček, První světová válka a česká otázka, (Praha: Triton, 2003); Michael Borovička et al., Velké dějiny zemí Koruny české, svazek XII. (18901918), (Praha - Litomyšl: Paseka, 2013).

2 Karel Pichlík, Bohumír Klípa, Jitka Zabloudilová, Českoslovenští legionáři (19141920), (Praha: Mladá fronta, 1996); František Emmert, Českoslovenští legionáři za první světové války, (Praha: Mladá fronta, 2014).

3 Šedivý, Češi, české země a Velká válka, 148-150; Arthur Rehberger, 1. světová válka 1914-1918. Rehabilitace c. k. vojáků ze zemí Koruny české padlých na jihozápadní frontě, (Příbram: Ivan Fojt, 2012), 23. 
because from the perspective on the interwar Czechoslovak Republic these soldiers fought for the "wrong side". After 1918 they were rather automatically grouped among the so-called Austrians, and some of the survivors were even discriminated as far as their career was concerned (in the Czechoslovak army, former legionnaires obtained higher ranks more quickly). ${ }^{4}$ The fallen Austro-Hungarian soldiers were not referred to as heroes, but at best as "unfortunate victims" of the war. They had already been forgotten during the interwar period, and forgetting continued throughout the more than forty years of the dominance of the communist regime in Czechoslovakia. After the political coup in 1948, the communists, who came to power, also repudiated the Czechoslovak legionnaires. The communists banned the Czechoslovak Association of Legionaries, blaming them because in the years between 1917 and 1920, during the so-called Siberian Anabasis, they came into conflict with the Russian Bolsheviks. Among all those who had participated in the First World War, after 1948 the Czechoslovak communists only glorified those Czech soldiers who entered the ranks of the Bolshevik Red Army after the Russian Revolution. ${ }^{5}$

In the German national camp as early as at the beginning of the First World War, the Czech soldiers serving in the Austro-Hungarian Army were considered as traitors or, at the very least, as unreliable soldiers who with their frequent desertions from the fronts (mainly on the Eastern Russian front) were allegedly sabotaging the efforts of loyal and valiant German and Hungarian soldiers fighting for the monarchy. The case of the Czech $28^{\text {th }}$ (Prague) Regiment was taken as an example of this dishonorable conduct, as a large part of them fell into Russian captivity during one of the great Russian offensives in the Carpathians, on Easter 1915. Afterwards, on April 1915, the Austrian Emperor Franz Joseph I decided that the $28^{\text {th }}$ Regiment should be "removed from the list of Austrian regiments for all time". ${ }^{6}$

The Czechs themselves also contributed to the image of the "unreliable Czech soldier". In the interwar years when they depicted their an-

4 Marie Koldinská, Ivan Šedivý, Válka a armáda v českých dějinách: sociohistorické črty, (Praha: Nakladatelství Lidové noviny, 2008), 159-164.

5 Emmert, Českoslovenští legionáři za první světové války, 219-220.

6 Josef Fučík, Osmadvacátníci. Spor o českého vojáka Velké války 1914-1918, (Praha: Mladá fronta, 2006). Regarding the $28^{\text {th }}$ Prague Regiment it is necessary to add that after the Czech soldiers in the spring of 1916 stood out in Italian front by the Soča River by driving back one of the most massive Italian offensives, the $28^{\text {th }}$ Prague Regiment was renewed on the basis of a decree by the Emperor in June 1916. 
ti-Austrian endeavors during the period of the war in the brightest colors possible. They made it seem as though just about every second Czech soldier had been a conscious "resistance fighter" against Austria-Hungary. And then there was the world-famous novel by the Czech author Jaroslav Hašek, The Fateful Adventures of the Good Soldier Švejk during the World War, in which the author attempted, in a humorous way, to laugh at the horrors and stupidity of the war. This work of fiction also played a definite role in the formation of the stereotype of a Czech soldier in the period of the First World War in the 1920s when it was widely read, and Švejk subsequently became a certain stereotype for a Czech soldier. This was particularly true abroad, where people subscribed to the oversimplified notion that Czech soldiers had mocked service to Austro-Hungarian Army and attempted to wait out the difficult wartime period with their proverbial deviousness and know-nothingism. ${ }^{7}$

The question arises: were all Czech soldiers in the First World War really "unreliable" and "devious"? Concerning this matter, it is necessary to say the following: the attitude of Czech historians to the subject of Czech soldiers' participation in the First World War underwent a significant change after the demise of the communist regime in Czechoslovakia in 1989. Since that time, historians have been attempting to gradually create more objective interpretations of the events of 1914-1918 and take a more intensive interest in the fates of the thousands of "forgotten" Czech soldiers who fought in the uniforms of the Austro-Hungarian Army. ${ }^{8}$ The evaluation of this very complicated subject has not been, until today, brought to its full completion within Czech historiography. Nonetheless, it is possible to formulate several partial answers to the above-mentioned question, as well as some generalizing theses.

1) It is true that Czech soldiers - as Slavs - were put into a complicated situation during the First World War. The Czechs could not identify with the outbreak of the military conflict, and this was mainly true of the liberally-minded and -behaving part of Czech society. They were not

7 Přemysl Blažíček, Haškův Švejk. Monografie, (Praha: Československý spisovatel, 1991).

8 At present, historians such as Ivan Šedivý (Faculty of Arts, Charles University, Prague) and Josef Fučík (Military History Institute, Prague) are in the context of Czech historiography those who most strive for providing an objective view of former soldiers of the Austro-Hungarian Army. In the Czech Republic, there are also many nonprofessional researchers, e.g. Arthur Rehberger or Jozef Vričan, who are interested in fates of Czech soldiers in Austro-Hungarian uniforms mainly because of the fact that some of their relatives were among the soldiers fallen during the Great War. 
entirely satisfied with Austria-Hungary (for which they were expected to fight) particularly as pertained to their political rights and their position within the Habsburg Monarchy. Psychologically, it was rather vexing for most Czechs, who in that period were characterized by strong Slavic sentiments, to have to fight against other Slavs, particularly against Russians, Serbs and Montenegrins, who were portrayed as "deadly enemies of the Habsburg Monarchy" by the Austrian wartime propaganda in $1914 .{ }^{9}$

The battle morale of Czech soldiers and their units, however, was not an absolute, unchanging value during the war. It differed fundamentally depending on the enemies the Czech soldiers faced in individual European theaters of war. On the Eastern (Russian) front, especially in the years 1914-1915, the morale of Czech soldiers strongly declined. Beside the moments of great self-sacrifice in battles, there were also certain cases of faltering, such as that of the above-mentioned Czech $28^{\text {th }}$ (Prague) Regiment. In connection with this, it is also necessary to admit that among Czechs, particularly at the outset of the war, there were strong expressions of Russophilia (which was at the same time also very naïve) and to a certain extent also Serbophilia. However, Czech historians today are of the opinion that Czech soldiers' desertions on the fronts of the First World War were not motivated either by conscious political animosity toward Austria-Hungary or pronounced Slavic sentiments. Rather, it was first and foremost caused by the aversion of the Czech soldiers toward the military institutions of the monarchy, and particularly toward commanders of the Austro-Hungarian Army who were not of Czech nationality. There were specific problems concerning the strict drill discipline and often a ruthless approach of German officers to their squadrons, which greatly antagonized the Czechs on the fronts (most of the high-ranking officers of the Austro-Hungarian Army in the first years of the war were of German or Hungarian nationality, and Czechs in the Army's higher functions were like hens' teeth). The tendencies of the Czech soldiers to desert to the other side or to decide to give themselves up to their adversaries on the front were often caused by the desperate situation on the front, particularly in the initial moments of very strong Russian offensives in the areas of Galicia and the Carpathians, and sometimes also by the general human instinct for self-preservation. ${ }^{10}$

On the other hand, Czech soldiers fought very determinedly in the First World War on the Southwestern (Italian) front. In the Austrian

9 Kvaček, První světová válka a česká otázka, 29-42.

10 Šedivý, Češi, české země a Velká válka, 149-150. 
Alps, and particularly in the watershed of the Soča River (Isonzo in Italian), which was the border between the Habsburg Monarchy and Italy at that time, and where battles were fought in the period 1915-1917 in the prevailingly rugged - and in winter frozen - mountainous terrain, and eventually by the Northern Italian Piave River (1918), where, by contrast in the unbearable heat and humidity from the marshlands, the Czechs fought very valorously. ${ }^{11}$ At this point, there arises the question of why the Czech soldiers fought so ferociously against the Italians. Several answers immediately impose themselves. For the Czechs, the Italians were to a certain extent a traditional enemy." Czech units had fought in Austrian Army formations against Italians already in 1848-1849, then again in 1859 at the battle of Solferino, and once more in 1866 at the battle of Custoza. The grandfathers and fathers of the Czech soldiers who departed for the Italian front in 1915 always described battles with the Italians as very fierce and bloody. Moreover, in 1915, the Czech soldiers perceived Italy as a contemptible state, for it was then when Italy betrayed its original allies Germany and Austria-Hungary for the sake of its visions of territorial gains. It was also known that the Italians were not partial to Slavs: the Czechs knew well how the Italians manifested their animosity toward the Slovenes and Croats in the Adriatic Sea region. The Italians had the tendency to think of the Slavs as a "culturally inferior, backward element" that was allegedly forced, because of its own political immaturity, to lean upon the Habsburgs and the Habsburg Monarchy. The Italians automatically classified the Czechs, together with the Slovenes and Croats, into their own category of "dyed-in-the-wool Austrians", even though they did not know them very well. For the intensity of its battles, in particular in the scope and ferocity of combat between infantry and artillery, and the use of the air force and poisonous gases, the Italian front was entirely comparable with the legendary Western (French) front. In sharply-pitched battles, mere seconds were decisive. Generally, a soldier did not have a choice: he had to kill as quickly as possible, or he risked being killed himself. The fact that Slovenes mainly lived along the Soča River also played a role in the emotional reckoning of the Czech soldiers in the Italian theater of war of where their "friends" and their "enemies" stood. The Czechs maintained positive contacts with the Slovenian villagers, even though it was only because they were trying to acquire in-

11 Josef Fučík, Soča (Isonzo), (Praha - Litomyšl: Paseka, 1999); Josef Fučík, Piava 1918, (Praha: Havran, 2001); Jozef Vričan, Po zapadlých stopách českých vojáků. Z Julských Alp kJadranu, (Olomouc: Ondřej Havlík, 2008). 
valuable food supplies from them during the war. Many Czech soldiers still recalled, after the war, about their sojourn among Slovenians on the Soča front, even including, for example, the renowned artist and writer Josef Váchal. ${ }^{12}$

Contemporary Czech historians have tallied up approximately 40-45 thousand Czech soldiers who were fighting in the Soča River Valley in the summer of 1917, when it was decided by the banks of the Soča River, whether the Italians would or would not be able to gain control of the largest Austro-Hungarian port of Trieste. This was in fact the greatest concentration of Czech soldiers in all their military history (in an open battle, in one concrete, territorially limited area). ${ }^{13} \mathrm{~A}$ great many Czech soldiers also fell in these battles along the Soča River. It is not possible to tell the precise number, though it was certainly in the range of thousands of dead. ${ }^{14}$ To this day, this is witnessed by a number of memorials and military cemeteries for Czech soldiers located in the borderlands of Italy and Slovenia. ${ }^{15}$ The approach to Trieste in the summer of 1917,

12 Josef Váchal, Malíř na frontě. Soča a Itálie 1917-1918, (Praha - Litomyšl: Paseka, 1996), 126-160.

13 Josef Fučík, Marek Pavlík, Sočská fronta 1915-1917. Průvodce po místech bojů vojáků z českých zemí, (Praha: Nakladatelství Elka Press, 2008), 55.

14 We only have individual case studies that address the numbers of fallen Czech soldiers in the Soča River Valley. Several years ago, an interesting dissertation was written on this subject at the Philosophical Faculty of Masaryk University in Brno: Eliška Papcunová, „Účast českých vojáků na sočské frontě za 1. světové války 19151917“, (PhD diss., Masaryk University of Brno, 2009). On the basis of documents compiled and published by the regional museum in the Slovenian town of Tolmin, this study investigated the numbers of Czech soldiers buried in military cemeteries that have been preserved till the present day and are still found in the region called the Upper Posočí i.e., in a region that extends roughly between the Slovenian cities of Bovec and Tolmin. In this roughly 50-kilometer-long segment of the former battle lines of the so-called Soča front have been preserved the graves of altogether 15,769 Austro-Hungarians. Among them, ethnic Czechs (judged by their typically Czech surnames), or people who have a documented origin in the Czech lands of the Habsburg Monarchy (among whom are naturally also included some Germans from the Czech lands), there were 1873 registered in the lists, which is about one eighth of the overall number. It can be assumed that a similar ratio also existed in other sectors of the Soča front.

15 Cemeteries of Czech soldiers from the First World War can also be found in Western Slovenia, for example, in the villages Brje pri Komnu, Dutovlje and Log pod Mangartom. In the last-mentioned cemetery there still stands a large sculptural group with an Austrian soldier from the so-called Mountain (Huntsmen's') Division along with a Bosnian soldier wearing the characteristic fez on his head. The sculptural group was created there in the years 1916-1917 by the Czech sculptor Ladislav Kofránek. 
specifically in the period of the so-called $10^{\text {th }}$ and $11^{\text {th }}$ Italian offensives on the Soča front, was managed by the Austro-Hungarian Army, due to, among other things, the courage and determination of many of its Czech units to resist the attacks (during the $10^{\text {th }}$ Italian offensive in May and June 1917 in the Southern sector of the Soča front in the vicinity of the Gulf of Trieste, the soldiers of the $21^{\text {st }}$ Infantry Regiment from Čáslav and the $28^{\text {th }}$ Infantry Regiment from Prague, particularly distinguished themselves. Also, during the $11^{\text {th }}$ Italian offensive in August and September 1917, in the central part of the Soča River's course, the soldiers of the $28^{\text {th }}$ Rifle Regiment from Písek and the $7^{\text {th }}$ Rifle Regiment from Plzeň defended themselves valiantly). ${ }^{16}$ But then the tables turned, and in October 1917 the Austro-Hungarian and German Armies launched their great counteroffensive by the Slovenian Kobarid (Caporetto in Italian) and beat back the Italian Army by more than one hundred kilometers westward toward the northern Italian Piave River, where battles thereafter raged all the way until the end of the First World War. The $3^{\text {rd }}$ Italian Army Command drafted the following report about the Austrian units waging war in the summer of 1917 at the Soča River: "When they are attacked [these] units fight, whether due to their discipline or their instinct for self-preservation. The hate propaganda [in the Austrian Army] against the Italians is vehement and tireless. The growth in the percentage of squadrons of Slavic nationality - before our front we now have 60 percent Slavs, 16 percent Hungarians, 13 percent Germans, and 11 percent Romanians - could give rise to the assumption that these units were going to have a reduced capability for resistance. However, experience has taught us that these Slavs, who have surrendered en masse on the other fronts, are striking on our front with particular relentlessness. It suffices to mention the Czechs, who with unrivalled tenacity defended themselves and would rather let themselves be killed in the trenches and shelters in the cliffs than surrender."17 The facts mentioned here about the conduct of Czech soldiers in battles on the Soča River enable us to state that the Czechs, along with the Slovenes, Croats, Bosnians, Austrian Germans and

Several other authors have treated the cemeteries of Czech soldiers in Slovenia in more detail in their works. See, e.g. Fučík, Pavlík, Sočská fronta 1915-1917, 176-180; and David Erik Pipan, „Spomenik hrabrim braniteljam Rombona“, Na fronti. Revija vojaške zgodovine 3 (2003), 48-52.

16 Fučík, Soča (Isonzo), 71-114.

17 Šedivý, Češi, české země a Velká válka, 137. 
other nationalities, belonged among the bulwarks of the Austro-Hungarian Army and they persevered on this front right until its absolute end. ${ }^{18}$

2) The battle morale of Czech soldiers during the First World War was not only influenced by national factors, but also very strongly by social factors. It is a well-known fact that men from the agrarian regions of the Austro-Hungarian Monarchy were generally more disciplined and stalwart soldiers during the war than the recruits from industrial and urban zones. The soldiers from the predominantly rural Alpine countries, especially the Muslim Bosnians, were usually given as examples of very loyal soldiers in the Austro-Hungarian Army; these particularly stood out for their truly great bravery and devotion to the Emperor. ${ }^{19}$ Czechs mostly hailed from the industrial areas of the Habsburg Empire and belonged to the better-educated units of the Austro-Hungarian Army. During the course of the war, the Austro-Hungarian soldiers from cities showed a greater tendency to desertion and willingness to surrender to the enemy. However, an exceptional operation that took place in September 1917 on the Italian front can be provided as an example supporting this statement - a group of Czech and South Slavic soldiers attempted to desert to the Italian side at the South Tyrolean Carzano. A commander of the group was a Slovenian lieutenant Ljudevit Pivko, a former teacher and a pre-war official of Sokol. He convinced several dozens of Czech, Slovenian and Croatian Austro-Hungarian Army soldiers to participate in this operation. The soldiers were mostly members of intelligentsia or people from technical professions. As Pivko describes this case in his post-war memoirs, preparations for the defection had to be concealed from Muslim soldiers from Bosnia, who mostly came from rural areas and the idea of "betraying the Army and the Emperor", for whom they were fighting on the front, was quite unconceivable. ${ }^{20}$

Czechs made up about 12 percent of all Austro-Hungarian soldiers. In the course of the First World War almost one million of them alternated service on the various fronts. They particularly excelled in the technically-based areas of the Army - in artillery divisions, in the Navy, as well as in the Air Force (the Czechs made up to one third of the

18 Fučík, Soča (Isonzo), 115-122.

19 Werner Schachinger, Die Bosniaken kommen. Elittentruppen k. u. k. Armee 18791918, (Graz - Stuttgart: Leopold Stocker Verlag, 1994); Zijad Šehić, U smrt za cara i domovinu! Bosanci i Hercegovci u vojnoj organizaciji Habsburške monarhije 1878.1918, (Sarajevo: IP Sarajevo Publishing, 2007).

20 Ljudevit Pivko, Proti Rakousku. Carzano, (Praha: Památník odboje, 1924). 
personnel in the Air Service).$^{21}$ A number of officers of Czech nationality were awarded high Austrian military honors for their accomplishments in combat during the war, and thousands more ordinary Czech soldiers were also honored for their selfless service and bravery. ${ }^{22}$ Czechs fought in the uniforms of the Austro-Hungarian Army in all the European theaters of war, and also, for example, in the Near East, where as artillerymen they defended Turkish positions on the coast of the Anatolian peninsula and in Palestine. ${ }^{23}$

3) Finally, it is also necessary to make a brief statement on the Czechoslovak legionnaires. They were indisputably very brave soldiers who, though their mere existence as well as the numerous military engagements (especially on the Russian and the Western fronts) made substantial political and military contribution toward the emergence of the independent Czechoslovak Republic. During the period 1919-1920, the legionnaires were those who, in the absence of an entirely regular Czechoslovak army, helped to safeguard the borders of the newly-established state. Nevertheless, it is still necessary to remark that their determination to enter the legions was not just an unambiguous desire to take part in the dismantling of Austria-Hungary. In the beginning, only Czech nationals who lived outside their homeland entered the first legionary divisions in France and Russia: it was only later that those who had already had, for various political and social reasons, a very critical relationship toward the Habsburg Monarchy and who additionally at the moment when the war broke out had also been strongly influenced by the Allied states' propaganda, joined. But it was even later - as late as in 1917 - that the Czech prisoners of war also began to enter the legions en masse. In the Europe of that time, this had already begun to manifest as a general weariness of the war: the Habsburg Monarchy was already strongly discredited among diverse strata of its population for its participation in the war, and it was starting to become ever more evident that further pursuit of this war was beyond the powers of Austria-Hungary. On the other hand, it was also at this time that the influence of the Allies' propaganda began to increase, as well as that of agitation by leaders of the Czechoslovak foreign emigration (principally T. G. Masaryk and M. R. Štefánik). The first significant military successes of the Czechoslovak

21 Fučík, Soča (Isonzo), 61-70.

22 Jiří Pernes et al., Pod císařským praporem. Historie habsburské armády 1526-1918, (Praha: Nakladatelství Elka Press, 2003), 409-472.

23 Pernes et al., Pod císařským praporem, 376. 
legions in Russia, particularly after their successful deployment in the battles at Zborov and Bakhmach also affected recruitment. However, it was then that the nationally conscious and politically radical Czechs, especially those who had been members of Sokol before the war, entered the Czechoslovak legions. In this context then, it is necessary to mention a postwar quote by T. G. Masaryk: "Without Sokol there would not have been legions; without the legions there would not have been Czechoslovakia!" ${ }^{24}$ However, after the war, many of the rank and file Czechoslovak legionnaires admitted that their primary motive for entering the legions had not been radical Czech patriotism, but an attempt to liberate themselves from the appalling and nearly unbearable conditions prevailing in the prisoner-of-war camps, particularly in the Russian ones. ${ }^{25}$

Arguing today, when one hundred years separates us from the outbreak of the First World War, which of the Czech soldiers, whether the legionnaires or soldiers in the uniforms of the Austro-Hungarian Army, were "braver" or even "better" soldiers in the years 1914-1918, would be in both factual and moral regards senseless. Czechoslovak legionnaires deserve a great share of the credit for the creation of the independent Czechoslovak Republic, and they are owed a great debt of appreciation for this. Appreciation and respect, however, are also owed to those Czech soldiers who were fighting in the units of the Austro-Hungarian Army, for in their case it is necessary to especially appreciate the fact that they faithfully fulfilled their civic duty - the promise given to the emperor and their homeland of that time: the Habsburg Empire.

It is doubtlessly well for the majority of contemporary Czech historians that the question of nationality is no longer the most important factor for evaluating such a complicated period as the First World War. The changed attitude of Czech historians as well as of the wider Czech society toward soldiers who fell between 1914 and 1918 became noticeable at the end of the $20^{\text {th }}$ century. At that time in the Czech Republic there was a rising and unprecedented wave of interest, particularly among young people, who began to investigate the fates of their grandfathers and great-grandfathers who had died in various uniforms - legionary and

24 Emmert, Českoslovenští legionáři za první světové války, 13.

25 Ibid., 38-62. 
Austro-Hungarian - during the First World War on European battlefields. In 1991, shortly after the fall of the communist regime, the activities of the Czechoslovak Association of Legionaries, which was to renew and uphold the traditions and legacy of the Czechoslovak legionnaires from the time of the Great War in the new era, was renewed in its homeland. In connection with this wave of seeking more objective "truths about the past" at the turn of the $20^{\text {th }}$ and $21^{\text {st }}$ centuries, the Czech government and Army also supported the construction of a number of monuments (principally in the Galicia area and in the region of the former Italian front in the borderlands between today's Italy, Austria and Slovenia), which should - although with a significant delay since the events took place - honor the memory of the fallen Czech soldiers in the uniforms of the Austro-Hungarian Army. We are convinced that this is a small, but very significant and valuable contribution towards forming a balanced (non-national) perspective on the European events that took place one hundred years ago.

\section{Literature}

- Blažíček, Přemysl. Haškův Švejk. Monografie. Praha: Československý spisovatel, 1991.

- Borovička, Michael et al. Velké dějiny zemí Koruny české, svazek XII, (1890-1918). Praha - Litomyšl: Paseka, 2013.

- Emmert, František. Českoslovenští legionáři za první světové války. Praha: Mladá fronta, 2014.

- Fučík, Josef, Osmadvacátníci. Spor o českého vojáka Velké války 19141918. Praha: Mladá fronta, 2006.

- Fučík, Josef. Soča (Isonzo). Praha - Litomyšl: Paseka, 1999.

- Fučík, Josef. Piava 1918, Praha: Havran, 2001.

- Fučík, Josef, Marek Pavlík. Sočská fronta 1915-1917. Průvodce po místech bojů vojáků z českých zemí. Praha: Nakladatelství Elka Press, 2008.

- Koldinská, Marie, Ivan Šedivý. Válka a armáda v českých dějinách: sociohistorické črty. Praha: Nakladatelství Lidové noviny, 2008.

- Kvaček, Kvaček. První světová válka a česká otázka. Praha: Triton, 2003.

- Papcunová, Eliška. „Účast českých vojáků na sočské frontě za 1. světové války 1915-1917“. PhD diss., Masaryk University of Brno, 2009.

- Pernes, Jiří et al., Pod císařským praporem. Historie habsburské armády 1526-1918. Praha: Nakladatelství Elka Press, 2003. 
- Pichlík, Karel, Bohumír Klípa, Jitka Zabloudilová. Českoslovenští legionáři (1914-1920). Praha: Mladá fronta, 1996.

- Pipan, David Erik. „Spomenik hrabrim braniteljam Rombona“. Na fronti. Revija vojaške zgodovine 3 (2003), 48-52.

- Pivko, Ljudevit. Proti Rakousku. Carzano. Praha: Památník odboje, 1924.

- Rehberger, Arthur. 1. světová válka 1914-1918. Rehabilitace c. k. vojáků ze zemí Koruny české padlých na jihozápadní frontě. Příbram: Ivan Fojt, 2012.

- Schachinger, Werner. Die Bosniaken kommen. Elittentruppen k. u. $k$. Armee 1879-1918. Graz - Stuttgart: Leopold Stocker Verlag, 1994.

- Šedivý, Ivan. Češi, české země a Velká válka 1914-1918. Praha: Nakladatelství Lidové noviny, 2001.

- Šehić, Zijad. U smrt za cara i domovinu! Bosanci i Hercegovci u vojnoj organizaciji Habsburške monarhije 1878.-1918. Sarajevo: IP Sarajevo Publishing, 2007.

- Váchal, Josef. Malíř na frontě. Soča a Itálie 1917-1918. Praha - Litomyšl: Paseka, 1996.

- Vričan, Jozef. Po zapadlých stopách českých vojáků. Z Julských Alp k Jadranu. Olomouc: Ondřej Havlík, 2008. 


\title{
Резиме
}

Ладислав Хладки

\section{Чешки војници у Великом рату (1914-1918)}

\begin{abstract}
Апстракт: Циљ овог чланка је да пружи објективни приказ понашања чешких војника у Првом светском рату. У прошлости је ово питање, због разних идеолошких разлога, у великој мери било упрошћено. Немачка национална пропаганда приказивала је чешке војнике који су се борили на страни аустроугарске војске 1914-1918. као непоуздан елемент, због словенског сентимента. Међутим, након 1918. чехословачка историографија је заузела веома критички став према овим војницима, јер је главна заслуга за оснивање независне Републике Чехословачке приписивана такозваним легионарима, тј. војницима који су се борили на страни савезничких држава. У овом чланку, аутор се ослања на чешку историографију на прелазу између XX и XXI века и покушава да пружи избалансирану (ненационалну) перспективу ове теме.
\end{abstract}

Кључне речи: Први светски рат, Аустроугарска, чешки војници, источни (руски) фронт, југозападни (италијански) фронт, чехословачки легионари, Република Чехословачка

Овај чланак представља покушај објективног приказа понашања чешких војника током Великог рата. Немачка и аустријска пропаганда у периоду од 1914. до 1918. нудила је превише поједностављен и неправедан портрет чешког војника као веома непоузданог фактора, па чак и као издајника аустријског цара и његове војске. Ово становиште је формирано на основу неколико случајева дезертирања чешких војних јединица које су биле у саставу аустроугарске војске, нарочито на источном (руском) фронту у периоду од 1914. до 1915. године. Међутим, након рата, званична чешка историографија заузела је критички став према чешким војницима који су се борили на страни Хабзбуршке монархије, а главна заслуга за оснивање не- 
зависне Републике Чехословачке приписана је такозваним чехословачким легионарима - војницима који су се добровољно придружили чехословачким јединицама (легијама) током рата и борили се против Немачке и Аустрије на страни савезничких трупа.

Циљ овог чланка је да пружи избалансиран приступ теми. Овај чланак се заснива на савременој чешкој литератури са прелаза XX у XXI век и покушава да докаже да су чешки војници који су се борили на страни аустроугарске војске, нарочито они који су се борили на италијанском фронту током Првог светског рата, у већини случајева били лојални и храбри и часно испуњавали своју грађанску дужност према цару и држави у којој су тада живели - Хабзбуршкој монархији. Током рата погинуло их је више од 130.000. У Чешкој Републици данас, легионари и војници бивше аустроугарске војске више не уживају различит третман. Свима је одато дужно поштовање и захвалност за жртве током Првог светског рата. 